\title{
Analysis and prognosis of bitter acids content in Czech hop varieties - year 2018 and long-term comparisons and trends
}

\author{
Alexandr Mikyška* , Marie Jurková \\ Research Institute of Brewing and Malting PIc, Lípová 15, CZ 12044 Praha 2 \\ ${ }^{\star}$ Corresponding author mikyska@beerresearch.cz
}

\begin{abstract}
This article presents the results of the harvest forecast of the alpha- and beta-bitter acids of the Czech hop varieties in the 2018 harvest, the results are discussed in relation to the long-term averages, the composition of the bitter acid analogs and the stability of the varietal characteristics. 180 hop samples were analyzed using EBC 7.7 (HPLC) method. The alpha-acid content of the most important Saaz variety (2.9\% in dry matter) was identical to the 2017 harvest and $18 \%$ rel. lower than the 26-year average. The alpha-acid content of Sladek (5.0\%), Premiant (4.8\%), and Saaz Late (1.6\%) varieties was significantly lower than the long-term average. The harvest of the hops of the Kazbek and Agnus varieties was close to the long-term average. The ratio of alpha- and beta-acids, the relative content of cohumulone and the relative content of colupulone were consistent with long-term averages for the tested varieties. It was confirmed, that the harvest forecast gives timely information on the alpha-acids content of the harvest, the results were in good agreement with the values of the final evaluation of all harvested hops samples.
\end{abstract}

Key words: hops harvest, Saaz hops, Sladek, Premiant, Agnus, Kazbek, Saaz Late, alpha acids, beta acids

\section{Introduction}

This paper presents the evaluation of the harvest forecast for the content of $\alpha$ - and $\beta$-bitter acids in significant Czech hop cultivars from the 2018 harvest. The evaluation of the $\alpha$ - and $\beta$-bitter acids of the harvested hops at the Research Institute of Brewing and Malting (RIBM) is carried out yearly and has been done since 1950. The analyzed samples were collected during the course of the whole harvest from all three growing areas in the Czech Republic. The values are harvest prediction based on the analysis $180-190$ hop samples. Evaluation of the whole harvest, all of purchased parts of hops performs Chmelařství družstvo and Hop Research Institute both using lead conductance value.

In 2004 the RIBM started the evaluation of other Czech hop varieties Sládek and Premiant which are important for domestic breweries (Mikyška 2010). The Agnus variety has also been evaluated since 2009 , aroma variety Kazbek since 2014, and in 2015 started the assessment of aroma variety Saaz Late, which was recommended by the RIBM for beer production according to PGI Czech beer in 2013 (Mikyška et al. 2013).

In 2018 the hop yard areas in the Czech Republic amounted to 5,020 ha which means an increase of 75 ha compare to 2017. Continued renovation of older stands, a total of 296 ha was planted. The Žatec area (Saaz) was spread over 3,856 ha, the Úštěk area (Auscha) 535 ha and the Tršice area (Tirschiz) over 629 ha. The most important variety is still the Saaz variety, it was cultivated on $86.6 \%$ of all hop yards in the Czech Republic in 2018. Other Czech varieties Sládek, Premiant, Agnus, Kazbek and Saaz Late cultivated on $6.4 \%, 3.4 \%, 0.8 \%, 0.7 \%$ and $0.9 \%$ of the hop yards, are from this point of view only minor varieties (Barborka 2019a)
In the year 2018 a yield of 5,126 tons of hops were harvested, the yield in 2018 is $24.6 \%$ lower than in the year 2017 (6,797 tons). In the Žatec area 3,989 tons of hops were harvested, in the Úštěk area 816 tons and in the Tršice area the yield amounted to 863 tons. The average yield was 1.02 tons/ha (Barborka 2019). Since 1994 the hop samples were analyzed by using a highly specific HPLC method in accordance with Analytica-EBC (method 7.7.) for the determination of $\alpha$ - and $\beta$ - bitter acids and their analogues (EBC Analyses Committee 2010).

In addition to the most important $\alpha$-bitter acids, $\beta$ bitter acids are also evaluated, which also influence the bitterness of beer (Dušek et al., 2014, Algazzali and Shellhammer, 2016). Therefore, results from 26 years of hop quality testing in the Czech Republic by this method are available. The results obtained using different methods are not fully comparable. The values obtained by lead conductance methods are generally higher than the values obtained by the HPLC method in accordance with Analytica EBC because the lead conductance value also covers additional components of the hop resins (Krofta et al. 2017).

The content and composition of hop resins as well as other secondary metabolites important for beer brewing and pharmaceutical industry, eg. hop oils and polyphenols is given primarily by genetically determined varietal specificity (Dressel et al., 2016). However, other factors, aggregate soil and climaticconditions (Forster and Gahr, 2014, Forteschi et al. 2019) weather conditions during vegetation andharvest in the given year, soil conditions of the locality, age of hop plants and viral infections are important (Jelínek et al, 2012, Kavalier et al 2011).

Polyphenol substances in the mass of hop cone are formed at earlier stages than the compounds contained in lupulin glands, resins, essential oils and prenylflavonoids. 
Table 1: Bitter acids content of Saaz variety in 2018 harvest in Žatec area (SD - standard deviation)

\begin{tabular}{|l|c|c|c|c|c|c|}
\hline & $\begin{array}{c}\alpha \text {-acids } \\
\% \mathrm{w} .\end{array}$ & $\begin{array}{c}\text { cohumulone } \\
\% \text { rel. }\end{array}$ & $\begin{array}{c}\alpha \text {-acids/ } \\
\beta \text {-acids }\end{array}$ & $\begin{array}{c}\beta \text {-acids } \\
\% \mathrm{w}\end{array}$ & $\begin{array}{c}\text { colupulone } \\
\% \text { rel. }\end{array}$ & $\begin{array}{c}\text { moisture } \\
\% \mathrm{w}\end{array}$ \\
\hline Average & 2.97 & 24.7 & 0.78 & 3.86 & 39.1 & 8.9 \\
\hline Maximum & 5.32 & 31.0 & 1.73 & 5.78 & 43.4 & 11.5 \\
\hline Minimum & 1.18 & 20.2 & 0.40 & 2.39 & 34.0 & 7.3 \\
\hline SD & 0.90 & 2.0 & 0.25 & 0.66 & 1.7 & 0.8 \\
\hline SD (\% rel.) & 30.2 & 8.2 & 31.6 & 17.0 & 4.3 & 9.1 \\
\hline Median & 2.90 & 24.8 & 0.72 & 3.97 & 39.0 & 8.8 \\
\hline
\end{tabular}

The course of weather at the time of the growth and ripening of hops and the date of harvesting can substantially influence the content, composition and ratios of secondary metabolites of hops (Kavalier et al 2011, Inui et al., 2017). It was also demonstrated that the composition of essential oils and pleasantness of hop aroma, has in addition to the time of harvest influenced by pruning time of hop plants (Inui et al, 2016). Thus, the reliability of the harvest prediction depends on the number and geographical distribution of hop samples included in the study.

\section{Materials and methods}

The samples of freshly harvested and dried hops were collected in collaboration with the Chmelařství, družstvo Žatec from batches supplied by Czech and Moravian hop producers during the harvest or immediately after the end of the harvest. The batches of hops dried in an industrial scale were sampled and transported to the RIBM. The number of samples corresponded to the harvest areas. The specific localities were selected in a way that the survey covers all growing areas - Žatec, Úštěk and Tršice. The analyses were conducted immediately after the delivery. The whole sample collection was analyzed using the HPLC-method in accordance with Analytica EBC, method 7.7 (EBC Analyses Committee 2010) for the determination of - and - bitter acids and their analogues. The water content was determined by drying $5 \mathrm{~g}$ of milled sample at a temperature of $105^{\circ} \mathrm{C}$ for 60 minutes.

\section{Results and discussion}

\subsection{Saaz variety}

\subsubsection{Saaz variety - Growing area Žatec}

All contents of bitter substances presented in this study are expressed as weight $\%$ in dry matter. The values obtained and their statistical evaluations are shown in the Table 1 . The average content of $\alpha$ - bitter acids in the hop samples examined from the Žatec area was $2.97 \%(2.70 \%$ in origin). This value was lower compared to the long-term average of the last 26 years. The difference from the long-term average was $0.58 \%$ ( $16.2 \%$ rel.). In comparison to 2017 the content was lower in $0.14 \%$ ( $4.9 \%$ rel.).
The overview of the $\alpha$ - and $\beta$-bitter acids contents in harvested over the last 26 years shows the Table 2 . The $\alpha$ - and $\beta$-bitter acids contents in the harvests during this period differed considerably. Since the peak values in 1996 the content $\alpha$-bitter acids in hops from the growing area Žatec and the total Czech Republic declined until the year 1999. The harvests in the years 2000 and 2001 were relatively in the good quality, significant decrease was observed in 2002 and 2003.

The hops harvested in the years 2004 and 2005 were average and the lowest values were reached in the harvest 2006. Since that year, the contents of $\alpha$-bitter acids in hops significantly increased. In 2010 the fall was recorded, below-average harvest. In the years 2011 and 2012 harvests were above average, while the 2013 harvest was slightly, the 2014 harvest markedly and harvest 2015 deeply below long-term average. In 2016 and 2017, the harvests from this point of view was slightly below average.

The harvest 2018 was extremely unbalanced, the relative standard deviation of $\alpha$-bitter acids content in the whole set of samples covering both standard and virus-free seedlings (ŽPČ ST and ŽPČ VF) was $30.2 \%$ (values $\alpha$-bitter acids varied from $1.18 \%$ to $5.33 \%$ ). The statistical distribution of the $\alpha$-acid contents (fig.1) showed that the majority of the samples, $28,6 \%$ rel. was in content group - $\alpha$-bitter acids content $2.5-3.0 \%$ (25.6\% rel.), $79.8 \%$ of the samples had a content in the range of $2.0-4.0 \%$ by weight in dry matter. The average content of $\beta$ - bitter acids of $3.86 \%$ (3.52\% in origin) was $0.81 \%$ ( $17.4 \%$ rel.) lower than the long-term average and $0.62 \%$ (13,8\% rel.) lower than the average value from the harvest in 2017. The ratio $\alpha$ - $/ \beta$-bitter acids was 0.63 . This value was lover compare to the average of the last 25 years $(0.76)$.

Both the relative content of cohumulone in the total $\alpha$-bitter acids $(24.7 \%$ rel. $)$ and the relative content of colupulone in the total $\beta$-bitter acids (39.1\% rel.) were in the range typical for the Saaz variety and was about the same when compared to the long-term average of cohumulone $(24.8 \%$ rel. $)$ and colupulone $(40.6 \%$ rel. $)$. The average water content in the tested samples was $8.9 \%$.

\subsubsection{Saaz variety - Growing area Úštěk}

The average content of $\alpha$-bitter acids in hop samples from the Úštěk area was $2.00 \%(1.82 \%$ in origin) (Table 3). The harvest balance was similar to Saaz growing area. The relative standard deviation for the values of $\alpha$-bitter acids in this group of samples was $32.9 \%$ and 
Table 2: Bitter acids content of Saaz variety in 1994 - 2018 harvests in growing areas (SD - standard deviation)

\begin{tabular}{|c|c|c|c|c|c|c|}
\hline Growing area & \multicolumn{2}{|c|}{ Žatec area } & \multicolumn{2}{|c|}{ Úštěk area } & \multicolumn{2}{|c|}{ Tršice area } \\
\hline Year & $\alpha$-acids & $\beta$-acids & $\alpha$-acids & $\beta$-acids & $\alpha$-acids & $\beta$-acids \\
\hline 1994 & 2.7 & 3.6 & 2.0 & 3.4 & 2.3 & 3.7 \\
\hline 1995 & 3.6 & 4.7 & 3.5 & 4.6 & 3.0 & 4.5 \\
\hline 1996 & 5.1 & 4.8 & 4.4 & 4.6 & 4.8 & 5.2 \\
\hline 1997 & 4.7 & 5.3 & 4.3 & 5.3 & 4.4 & 5.9 \\
\hline 1998 & 4.1 & 5.2 & 3.4 & 5.5 & 3.4 & 4.8 \\
\hline 1999 & 3.5 & 5.0 & 3.1 & 4.8 & 3.4 & 4.7 \\
\hline 2000 & 4.0 & 5.6 & 4.2 & 5.7 & 4.1 & 5.4 \\
\hline 2001 & 4.1 & 5.1 & 4.2 & 5.4 & 3.8 & 5.3 \\
\hline 2002 & 3.2 & 5.0 & 3.3 & 5.1 & 2.3 & 4.3 \\
\hline 2003 & 3.2 & 4.5 & 3.1 & 4.5 & 3.3 & 4.3 \\
\hline 2004 & 3.9 & 4.4 & 3.5 & 4.2 & 4.5 & 5.4 \\
\hline 2005 & 3.6 & 4.7 & 3.7 & 5.2 & 3.7 & 4.6 \\
\hline 2006 & 2.3 & 4.2 & 2.2 & 4.3 & 2.4 & 3.6 \\
\hline 2007 & 2.9 & 4.6 & 3.1 & 4.7 & 2.5 & 4.2 \\
\hline 2008 & 3.8 & 4.6 & 3.8 & 4.9 & 3.3 & 4.5 \\
\hline 2009 & 4.1 & 4.9 & 3.7 & 4.7 & 3.6 & 4.6 \\
\hline 2010 & 3.1 & 5.2 & 3.1 & 4.8 & 2.5 & 4.5 \\
\hline 2011 & 4.3 & 5.2 & 4.1 & 5.0 & 4.1 & 5.0 \\
\hline 2012 & 4.2 & 4.8 & 4.0 & 4.9 & 3.8 & 4.6 \\
\hline 2013 & 3.5 & 3.7 & 3.2 & 3.5 & 2.9 & 3.0 \\
\hline 2014 & 3.1 & 4.5 & 2.7 & 4.3 & 2.7 & 3.7 \\
\hline 2015 & 2.2 & 3.2 & 2.1 & 3.2 & 2.2 & 3.3 \\
\hline 2016 & 3.4 & 5.1 & 3.4 & 4.8 & 3.1 & 4.4 \\
\hline 2017 & 2.8 & 4.5 & 2.9 & 4.6 & 2.6 & 3.8 \\
\hline 2018 & 3.0 & 3.9 & 2.0 & 4.0 & 3.4 & 4.1 \\
\hline Average & 3.5 & 4.7 & 3.3 & 4.6 & 3.3 & 4.5 \\
\hline
\end{tabular}

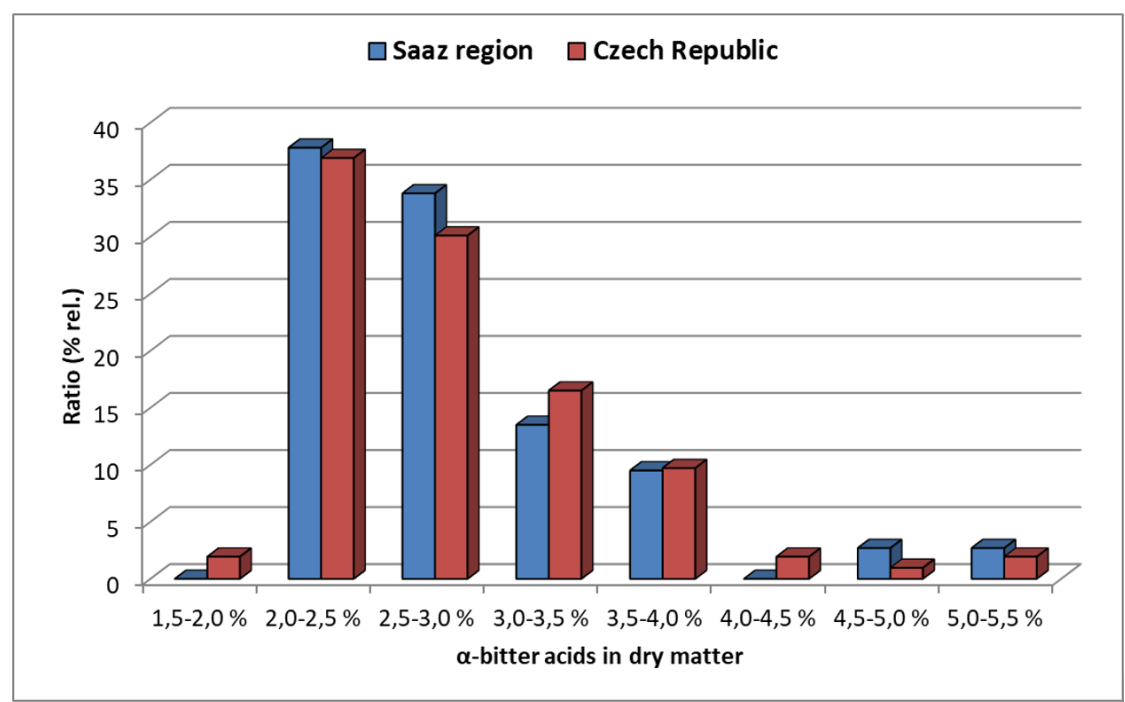

Figure 1: Distribution of $\alpha$-bitter acids content of Saaz hops harvested in 2018

]smallthe values varied from $0.70 \%$ to $2.95 \%$. The average value for $\alpha$-bitter acids was lower to the average for the last 26 years of monitoring in $1.34 \%(40.1 \%$ rel. $)$ and in $0.88 \%$ (30.6\% rel.) comparing to 2017 (Table 2).

The content of $\beta$-bitter acids of $4.02 \%$ (3.66\% in origin) was lower to the average for the last 26 years of monitoring in $0.66 \%$ (14.2\% rel.) and in $0.57 \%$ (12.4\% rel.) comparing to 2017 . The $\alpha$ - $/ \beta$-bitter acids ratio was 0.50 . This value was below the long-term average $(0.71)$ for this area. Both the relative content of cohumulone in the total $\alpha$-bitter acids $(23.7 \%$ rel.) and the relative content of colupulone in the total $\beta$-bitter acids $(37.5 \%$ rel.) were virtually identical to the long-term average values for this area $(24.5 \%$ rel. and $40.3 \%$ rel. $)$. The average water 
Table 3: Bitter acids content of Saaz variety in 2018 harvest in Úštěk area (SD - standard deviation)

\begin{tabular}{|l|c|c|c|c|c|c|}
\hline & $\begin{array}{c}\alpha \text {-acids } \\
\% \mathrm{w} .\end{array}$ & $\begin{array}{c}\text { cohumulone } \\
\% \text { rel. }\end{array}$ & $\begin{array}{c}\alpha \text {-acids/ } \\
\beta \text {-acids }\end{array}$ & $\begin{array}{c}\beta \text {-acids } \\
\% \mathrm{w}\end{array}$ & $\begin{array}{c}\text { colupulone } \\
\% \text { rel. }\end{array}$ & $\begin{array}{c}\text { moisture } \\
\% \mathrm{w}\end{array}$ \\
\hline Average & 2.00 & 23.7 & 0.48 & 4.02 & 37.5 & 9.0 \\
\hline Maximum & 2.95 & 27.2 & 0.61 & 4.82 & 39.9 & 9.6 \\
\hline Minimum & 0.70 & 20.5 & 0.24 & 2.92 & 34.6 & 8.4 \\
\hline SD & 0.66 & 2.1 & 0.12 & 0.55 & 1.5 & 0.3 \\
\hline SD (\% rel.) & 32.9 & 8.7 & 24.0 & 13.6 & 4.0 & 3.3 \\
\hline Median & 2.12 & 23.3 & 0.50 & 4.13 & 37.7 & 9.0 \\
\hline
\end{tabular}

Table 4: Bitter acids content of Saaz variety in 2018 harvest in Tršice area (SD - standard deviation)

\begin{tabular}{|l|c|c|c|c|c|c|}
\hline & $\begin{array}{c}\alpha \text {-acids } \\
\% \mathrm{w} .\end{array}$ & $\begin{array}{c}\text { cohumulone } \\
\% \text { rel. }\end{array}$ & $\begin{array}{c}\alpha \text {-acids/ } \\
\beta \text {-acids }\end{array}$ & $\begin{array}{c}\beta \text {-acids } \\
\% \mathrm{w}\end{array}$ & $\begin{array}{c}\text { colupulone } \\
\% \text { rel. }\end{array}$ & $\begin{array}{c}\text { moisture } \\
\% \mathrm{w}\end{array}$ \\
\hline Average & 3.37 & 23.7 & 0.84 & 4.13 & 39.4 & 8.8 \\
\hline Maximum & 5.08 & 26.6 & 1.46 & 4.91 & 42.1 & 9.4 \\
\hline Minimum & 2.19 & 22.3 & 0.58 & 3.03 & 36.6 & 8.1 \\
\hline SD & 0.82 & 1.0 & 0.28 & 0.58 & 1.3 & 0.4 \\
\hline SD (\% rel.) & 24.2 & 4.2 & 33.8 & 14.1 & 3.3 & 4.1 \\
\hline Median & 3.14 & 23.6 & 0.72 & 4.35 & 39.1 & 8.7 \\
\hline
\end{tabular}

content in the samples tested was $9.0 \%$.

\subsubsection{Saaz variety - Growing area Tršice}

The average content of $\alpha$-bitter acids in hop sam-ples from the Tršice area was $3.37 \%$ (3.08\% in origin)(Table 4$)$. The harvest was homogeneous similarly to the Saaz growing area. The relative standard deviation for the values of $\alpha$ bitter acids in this group of samples was $24.2 \%$ and the values varied from $2.19 \%$ to $5.08 \%$. The content of $\alpha$ - bitter acids was comparable to the average for the last 26 years and $0.81 \%$ (31.6\% rel.) higher than in 2017

(Table 2). The content of $\beta$-bitter acids in hops was $4.13 \%$ (3.77\% in origin). This value was $0.38 \%$ ( $8.5 \%$ rel.) lower than the average for the last 26 years and $0.29 \%$ $(7.6 \%$ rel.) lower than the value of harvest in 2017 . The $\alpha$ - $/ \beta$-bitter acids ratio was 0.82 . This value was higher compared to the long-term average (0.73). Both the relative content of cohumulone in the total $\alpha$-bitter acids $(23.7 \%$ rel.) and the relative content of colupulone in the total $\beta$-bitter acids (39.4\%) were very similar to the long-term average values for this area $(25.1 \%$ rel. and $40.5 \%$ rel.). The average water content in the tested samples was $8.8 \%$.

\subsubsection{Saaz variety - Whole Czech Republic}

The average content of $\alpha$-bitter acids in hop samples from throughout the Czech Republic was 2.89\% (2.64\% in origin) (Table 5). The relative standard deviation from the average value of the $\alpha$-acid content was $32.5 \%$ and the values varied from $0.70 \%$ to $5.32 \%$. The average value was $-0,62 \%(-17.6 \%$ rel.) lower when compared to the average for the last 26 years and similar to the average in 2017. The harvest was largely unbalanced. The relative standard deviation from the mean $\alpha$-bitter acid content was $32.5 \%(\alpha$-acid in the range of $0.70 \%-5.32 \%)$. The frequency distribution of the $\alpha$-acids content (Figure 1) shows that the highest proportion, $25.3 \%$ of the samples were $2.5-3.0 \%$ by weight in the dry matter content, $75.8 \%$ of the samples were in the range of $2.0-4.0 \%$ by weight in dry matter. The average content of $\beta$-bitter acids was $3.92 \%$ (3.58\% in origin). It was $0.74 \%$ ( $15.9 \%$ rel.) lower compared to the long-term average and $0.49 \%(11.1 \%$ rel.) lower in comparison with the year 2017.

The $\alpha$ - $/ \beta$-bitter acids ratio was 0.74 . This value was identical with the long-term average $(0.75)$. Considerable superiority of $\beta$ - bitter acids was in harvests 2006, 2007, 2010, 2014 - 2017, whereas the content of $\alpha$ - and $\beta$ - bitter acids nearly balanced for example in 2013 (Table 2). Both the relative content of cohumulone in the total $\alpha$-bitter acids $(23.7 \%$ rel. $)$ and the relative content of colupulone in the total $\beta$-bitter acids ( $39.4 \%$ rel.) were in the range typical for the Saaz variety and similar to the long-term average (cohumulone $25.1 \%$ rel., colupulone $40.5 \%$ rel.). The average water content was $8.8 \%$.

\subsection{Other Czech varieties}

\subsubsection{Sládek Variety}

The average content of $\alpha$-bitter acids in the tested hop samples of the Sládek variety was $4.96 \%$ (4.54\% in origin). The average content of the $\beta$-bitter acids was $3.74 \%$ (3.42\% in origin) (Table 6$)$. At the RIBM, the Sládek variety has been tested since the year 2004. Due to an insufficient number of samples the Sládek and Premiant varieties were not examined in 2007. In terms of the content of $\alpha$-bitter acids the quality of the 2018 harvest was below the average, $1.56 \%$ (33.9\% rel) lower compared to the last 15 years average value and $1.47 \%$ (22.9\% rel.) lower than the values from the year 2017. The content of $\beta$-bitter acids was in $2.09 \%$ (35.9\% rel) lower compared to the long-term average and 2.14 (36.5\% rel.) lower compare to the harvest in 2017 (Table 7). 
Table 5: Bitter acids content of Saaz variety in 2018 harvest in the Czech Republic (SD - standard deviation, ST - Standard seed, VF - Virus-free seed)

\begin{tabular}{|l|c|c|c|c|c|c|}
\hline & $\begin{array}{c}\alpha \text {-acids } \\
\% \mathrm{w} .\end{array}$ & $\begin{array}{c}\text { cohumulone } \\
\% \text { rel. }\end{array}$ & $\begin{array}{c}\alpha \text {-acids/ } \\
\beta \text {-acids }\end{array}$ & $\begin{array}{c}\beta \text {-acids } \\
\% \mathrm{w}\end{array}$ & $\begin{array}{c}\text { colupulone } \\
\% \text { rel. }\end{array}$ & $\begin{array}{c}\text { moisture } \\
\% \mathrm{w}\end{array}$ \\
\hline Average & 2.89 & 24.4 & 0.74 & 3.92 & 38.9 & 8.9 \\
\hline Maximum & 5.32 & 31.0 & 1.73 & 5.78 & 43.4 & 11.5 \\
\hline Minimum & 0.70 & 20.2 & 0.24 & 2.39 & 34.0 & 7.3 \\
\hline SD & 0.94 & 2.0 & 0.26 & 0.64 & 1.7 & 0.7 \\
\hline SD (\% rel.) & 32.5 & 8.0 & 35.2 & 16.3 & 4.4 & 7.9 \\
\hline Median & 2.86 & 24.5 & 0.69 & 4.06 & 38.8 & 8.8 \\
\hline Average ST & 3.00 & 24.4 & 0.78 & 3.92 & 39.2 & 8.9 \\
\hline Average VF & 2.59 & 24.5 & 0.65 & 3.92 & 38.2 & 8.9 \\
\hline
\end{tabular}

Table 6: Bitter acids content of Sládek variety in 2018 harvest in the Czech Republic (SD - standard deviation)

\begin{tabular}{|l|c|c|c|c|c|c|}
\hline & $\begin{array}{c}\alpha \text {-acids } \\
\% \mathrm{w} .\end{array}$ & $\begin{array}{c}\text { cohumulone } \\
\% \text { rel. }\end{array}$ & $\begin{array}{c}\alpha \text {-acids/ } \\
\beta \text {-acids }\end{array}$ & $\begin{array}{c}\beta \text {-acids } \\
\% \mathrm{w}\end{array}$ & $\begin{array}{c}\text { colupulone } \\
\% \text { rel. }\end{array}$ & $\begin{array}{c}\text { moisture } \\
\% \mathrm{w}\end{array}$ \\
\hline Average & 4.96 & 26.3 & 1.39 & 3.73 & 48.0 & 8.4 \\
\hline Maximum & 7.71 & 30.6 & 2.32 & 5.41 & 52.0 & 9.5 \\
\hline Minimum & 2.32 & 23.5 & 0.60 & 2.41 & 44.9 & 7.3 \\
\hline SD & 1.53 & 2.1 & 0.54 & 0.60 & 1.9 & 0.7 \\
\hline SD (\% rel.) & 30.8 & 8.1 & 39.2 & 16.1 & 4.0 & 7.8 \\
\hline Median & 4.69 & 26.0 & 1.15 & 3.72 & 47.9 & 8.6 \\
\hline
\end{tabular}

The Hop Research Institute in Žatec (Nesvadba et al 2012) gives a range from 4.5 to $8.0 \%$ as a typical for the $\alpha$-acid content and a range from 4.0 to $7.0 \%$ as a typical for the $\beta$-acid content in the Sládek variety. The relative standard deviation for the values of $\alpha$-bitter acids in this group of samples was $30.8 \%$. The $\alpha$-bitter acids content ranged from $2.32 \%$ to $7.71 \%$. Statistical distribution of the values showed the highest representation in the classes of $4.0-5.0 \%(24.0 \%$ of samples $)$ and $6.0-7.0(20.0 \%$ of samples, $76 \%$ of the samples ranged from 3.0-7, 0 (Figure 2).

The ratio $\alpha$-/ $\beta$-bitter acids was 1.33 and it is in the range presented by the Hop Research Institute in Žatec $(0.70$ to 1.30$)$. The relative content of cohumulone in the total $\alpha$-bitter acids $26.3 \%$ rel. and the relative content of colupulone in the total $\beta$-bitter acids $48.0 \%$ rel. were in the ranges given for this variety; for cohumulone values from 23 to $30 \%$ rel. and for colupulone values from 44 to $50 \%$ rel. They were also in agreement with the average from the last 15 years $(25.7 \%$ rel. and $48.7 \%$ rel.). The average water content was $8.4 \%$.

\subsubsection{Premiant Variety}

The average content of $\alpha$-bitter acids in the tested hops of the Premiant variety was $4.82 \%$ ( $4.42 \%$ in origin). The average content of $\beta$-bitter acids was $3.59 \%$ (3.29\% in origin) (Table 8 ). The average $\alpha$-bitter acid content in the 2018 harvest was lower by $3.75 \%$ (43.7\% rel.) Compared to the average for 15 years and by $2.83 \%$ (37.0\% relative) lower than the 2017 harvest. The $\beta$-bitter acid content was lower than the long-term average by 1.39 (28.0\% rel.) And by $2.07 \%$ (36.6\% rel.) Lower than the 2017 harvest (Table 7).

The Hop Research Institute in Žatec (Nesvadba et al 2012) gives a range from 7 to $10 \%$ as a typical for the $\alpha$-acid content and a range from 3.5 to $5.5 \%$ as a typical for the $\beta$-acid content in the Premiant variety.

The quality of Premiant hops in terms of $\alpha$-bitter acids content was relatively balanced, the relative standard deviation was $18.2 \%$. The $\alpha$-bitter acids content ranged from $3.30 \%$ to $6.85 \%$. The statistical distribution of $\alpha$-bitter acids content showed the highest proportion in two classes $4.0-5.0$ and $5.0-6.0$ (in every $33 \%$ of the samples), another $25 \%$ of samples were in the class $3.0-4,0$ (Figure 3 ). The ratio $\alpha$ - $/ \beta$-bitter acids was 1.35 , this value is below the range reported by the Hop Research Institute $(1.70-2.30)$. The relative contents of cohumulone in the total $\alpha$-bitter acids $28.1 \%$ and of colupulone in the total $\beta$-acid $50.3 \%$ were in the range given for this variety (cohumulone $18-23 \%$ rel. and colupulone $39-44 \%$ rel.). The average water content was $8.2 \%$.

\subsubsection{Agnus Variety}

The average content of $\alpha$-bitter acids in tested hop samples of the Agnus variety was $10.9 \%$ (10.0\% in origin). The average content of $\beta$-bitter acids was $5.18 \%(4.76 \%$ in origin) (Table 9). This variety has been evaluated at the RIBM for the tent year. The $\alpha$-bitter acid content was virtually the same as the 10-year average and the 2017 harvest. Content of $\beta$-bitter acids was in 0.87 (14.3\% rel.) 
Table 7: Bitter acids content of Sládek. Premiant and Agnus varieties in harvests of 2004 - 2018 in the Czech Republic (SD - standard deviation)

\begin{tabular}{|c|c|c|c|c|c|c|}
\hline \multirow{2}{*}{$\begin{array}{c}\text { Variety } \\
\text { Year }\end{array}$} & \multicolumn{2}{|c|}{ Sládek } & \multicolumn{2}{c|}{ Premiant } & \multicolumn{2}{c|}{ Agnus } \\
\cline { 2 - 7 } & $\alpha$-acids & $\beta$-acids & $\alpha$-acids & $\beta$-acids & $\alpha$-acids & $\beta$-acids \\
\hline 2004 & 5.8 & 5.5 & 9.8 & 4.4 & - & - \\
\hline 2005 & 6.8 & 7.1 & 9.0 & 5.3 & - & - \\
\hline 2006 & 6.5 & 6.5 & 7.6 & 6.0 & - & - \\
\hline 2007 & - & - & - & - & - & - \\
\hline 2008 & 6.6 & 6.1 & 10.2 & 4.8 & - & - \\
\hline 2009 & 7.3 & 7.2 & 11.0 & 5.1 & 13.5 & 6.6 \\
\hline 2010 & 7.3 & 6.4 & 9.7 & 5.9 & 11.2 & 7.1 \\
\hline 2011 & 8.2 & 5.8 & 10.1 & 5.2 & 11.0 & 6.1 \\
\hline 2012 & 7.0 & 5.2 & 8.9 & 5.1 & 12.1 & 6.0 \\
\hline 2013 & 6.2 & 5.1 & 8.4 & 4.2 & 11.2 & 5.6 \\
\hline 2014 & 5.8 & 6.1 & 7.2 & 5.8 & 9.7 & 6.2 \\
\hline 2015 & 5.1 & 4.4 & 6.6 & 3.3 & 10.5 & 4.9 \\
\hline 2016 & 7.3 & 6.4 & 9.0 & 5.5 & 9.7 & 6.3 \\
\hline 2017 & 6.4 & 5.9 & 7.7 & 5.7 & 11.0 & 6.3 \\
\hline 2018 & 5.0 & 3.7 & 4.7 & 3.5 & 10.9 & 5.2 \\
\hline Average & 6.5 & 5.8 & 8.6 & 5.0 & 11.1 & 6.0 \\
\hline
\end{tabular}

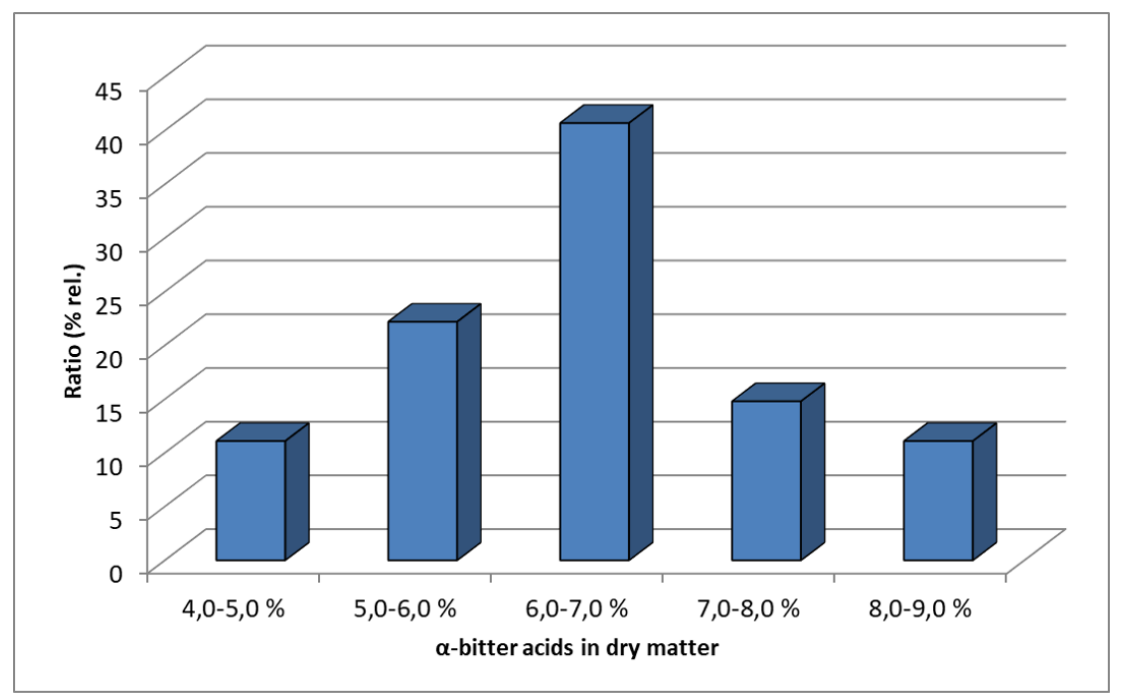

Figure 2: Distribution of $\alpha$-bitter acids content of Sládek hops harvested in 2018

lower compared to the long-term average and $1.14 \%$ (18.0\% rel.) lower compare to the harvest in 2017 (Table 7). According to the Hop Research Institute in Žatec (Nesvadba et al 2012) typical values for the -acid for the Agnus variety range from 9 to $12 \%$ whilst typical values for the -acid content vary from 4 to $6.5 \%$.

The $\alpha$ - $/ \beta$-bitter acids ratio was 2.11 . This value was below the range referred ( 1.90 to $2.60 \%$ ). The relative contents of cohumulone in the total $\alpha$ - bitter acids of $28.1 \%$ and of colupulone in the total $\beta$-bitter acids of $50.3 \%$ were in the range specified for this variety (cohumulone 29 $38 \%$ rel., colupulone $51-59 \%$ rel.). The average water content was $8.2 \%$.

\subsubsection{Kazbek Variety}

The average content of $\alpha$-bitter acids in tested hop samples of the Kazbek variety was $4.68 \%$ (4.29\% in origin). The average content of $\beta$-bitter acids was $4.82 \%$ ( $4.42 \%$ in origin) (Table 10$)$. This variety has been evaluated at the RIBM for the five year. The content of $\alpha$-bitter acids was comparable to the 5-year average and it was in $0.97 \%$ (17.2\% rel.) lover compared to the 2017 harvest. The $\beta$-bitter acids content was the similar both to the 5-year average and the 2017 harvest (Table 7).

According to the Hop Research Institute in Žatec (Nesvadba et al 2012) typical values for the $\alpha$-acid for the Kazbek variety range from 5 to $8 \%$ whilst typical values for the $\beta$-acid content vary from 4 to $6 \%$. The $\alpha$ - $/ \beta$-bitter acids ratio was 0.97 . This value was in the range referred $(0.90$ to $1.50 \%)$. Relative contents of cohumulone in the total $\alpha$-bitter acids of $34.7 \%$ and of colupulone in the total $\beta$-bitter acids of $56.5 \%$ were in the range specified for this variety (cohumulone $35-40 \%$ rel., colupulone $57-62 \%$ rel.). The average water content was $8.3 \%$. 
Table 8: Bitter acids content of Premiant variety in 2018 harvest in the Czech Republic (SD - standard deviation)

\begin{tabular}{|l|c|c|c|c|c|c|}
\hline & $\begin{array}{c}\alpha \text {-acids } \\
\% \mathrm{w} .\end{array}$ & $\begin{array}{c}\text { cohumulone } \\
\% \text { rel. }\end{array}$ & $\begin{array}{c}\alpha \text {-acids/ } \\
\beta \text {-acids }\end{array}$ & $\begin{array}{c}\beta \text {-acids } \\
\% \mathrm{w}\end{array}$ & $\begin{array}{c}\text { colupulone } \\
\% \text { rel. }\end{array}$ & $\begin{array}{c}\text { moisture } \\
\% \mathrm{w}\end{array}$ \\
\hline Average & 4.65 & 20.5 & 1.31 & 3.54 & 39.2 & 8.3 \\
\hline Maximum & 6.85 & 27.8 & 1.92 & 4.74 & 42.2 & 9.8 \\
\hline Minimum & 0.64 & 17.7 & 0.26 & 2.43 & 36.8 & 7.5 \\
\hline SD & 1.19 & 2.3 & 0.30 & 0.54 & 1.7 & 0.6 \\
\hline SD (\% rel.) & 25.5 & 11.0 & 23.0 & 15.4 & 4.4 & 6.8 \\
\hline Median & 4.70 & 20.1 & 1.27 & 3.50 & 38.9 & 8.4 \\
\hline
\end{tabular}

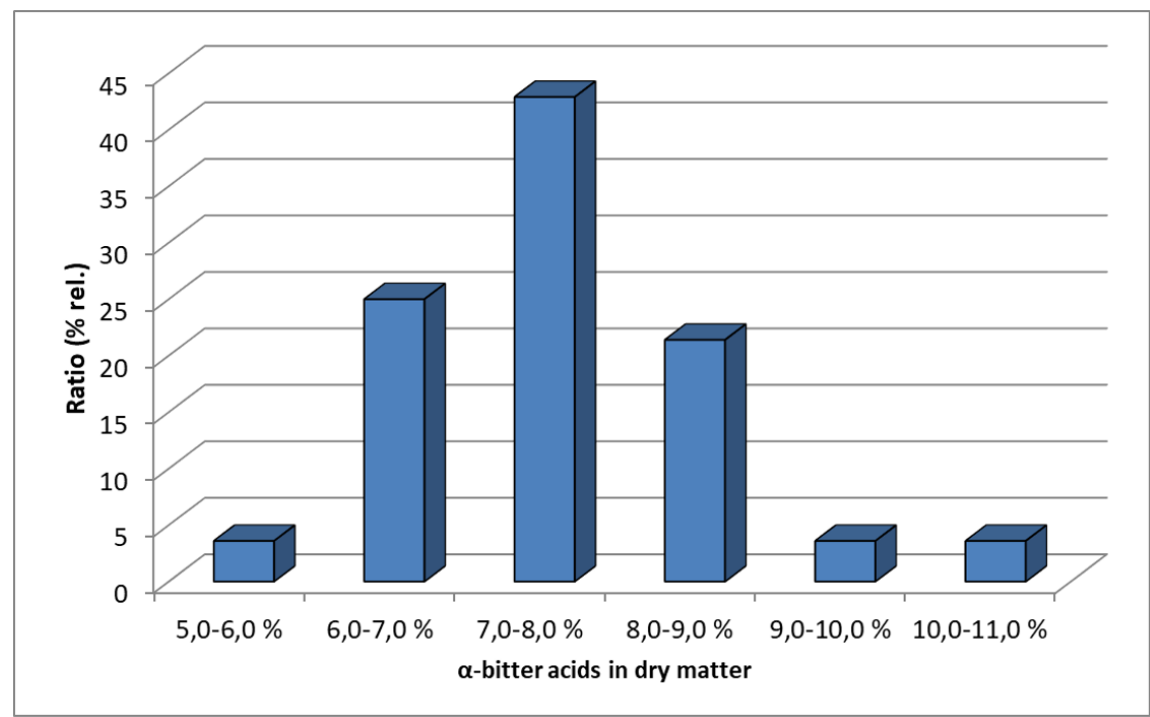

Figure 3: Distribution of $\alpha$-bitter acids content of Premiant hops harvested in 2018

\subsubsection{Saaz Late Variety}

The average content of $\alpha$-bitter acids in tested hop samples of the Saaz Late variety was $1.57 \%(1.44 \%$ in origin) (Table 11). The $\alpha$-bitter acids content was $1,30 \%$ ( $45.3 \%$ rel.) lower than the 4 -year average and by $1.87 \%$ (54.4\% rel.) lower compared with the 2017 harvest. The average content of $\beta$-bitter acids was $3.87 \%(3.47 \%$ in origin). The $\beta$-bitter acid content was $0.64 \%$ (14.5\% rel.) lower than the 4-year average and by $1.11 \%$ (22.7\% rel.) lower compared with the 2017 harvest. According to the Hop Research Institute in Žatec (Nesvadba et al 2012) typical values for the $\alpha$-acid for the Saaz Late variety range from 3.5 to $6.0 \%$ whilst typical values for the $\beta$-acid content vary from 4.0 to $6.5 \%$.

The $\alpha / \beta$-bitter acids ratio was 0.42 . This value was upper of low limit of the range referred (0.8 to $1.0 \%)$. The relative contents of cohumulone in the total $\alpha$-bitter acids of $26.2 \%$ and the content of colupulone in the total $\beta$-bitter acids of $38.6 \%$ was in the range specified for this variety (cohumulone $20-25 \%$ rel., colupulone $39-43 \%$ rel.). The average water content was $8.0 \%$.

\section{Conclusion}

In 2018 samples of freshly harvested, dried hops were taken during or immediately after the harvest, and analyzed for $\alpha$-bitter acids and $\beta$-bitter acids, including their analogs. Analyzes were performed by EBC analysis (Method 7.7). It was found that the average content of $\alpha$-bitter acids in hops samples of the most significant variety, Saaz variety, was $2.89 \%$ by weight in dry matter. The value was $0.62 \%$ $(17.6 \%$ rel.) Lower than the average for the last 26 years and practically the same as the 2017 harvest.

The content of $\alpha$-bitter acids in samples of hops of the Sladek variety in the 2018 harvest $(4.96 \%)$ was lower by $22.9 \%$ relative to the harvest in 2017 , the Premiant variety from the 2018 harvest $(4.82 \%)$ was by $37.0 \%$ rel. lower than the 2017 harvest, for the Agnus variety (10.9\%), the content of $\alpha$-bitter acids was identical to that of the 2017 harvest, for the Kazbek variety from the 2018 harvest $(4.68 \%)$, the $\alpha$-bitter acids content was in $2 \%$ rel. lower than the 2017 harvest, and in the Saaz Late variety (1.57), the $\alpha$-bitter acids content was lower by $54.4 \%$ rel. to the 2017 harvest. The ratio of $\alpha$-acids to $\beta$-acids, the relative content of cohumulone in total -acids and the relative content of colupulone in total $\beta$-acids was consistent with long-term averages for the tested varieties. 
Table 9: Bitter acids content of Agnus variety in 2018 harvest in the Czech Republic (SD - standard deviation)

\begin{tabular}{|l|c|c|c|c|c|c|}
\hline & $\begin{array}{c}\alpha \text {-acids } \\
\% \mathrm{w} .\end{array}$ & $\begin{array}{c}\text { cohumulone } \\
\% \text { rel. }\end{array}$ & $\begin{array}{c}\alpha \text {-acids/ } \\
\beta \text {-acids }\end{array}$ & $\begin{array}{c}\beta \text {-acids } \\
\% \mathrm{w}\end{array}$ & $\begin{array}{c}\text { colupulone } \\
\% \text { rel. }\end{array}$ & $\begin{array}{c}\text { moisture } \\
\% \mathrm{w}\end{array}$ \\
\hline Average & 10.91 & 28.1 & 2.13 & 5.18 & 50.3 & 8.2 \\
\hline Maximum & 13.50 & 29.3 & 2.77 & 5.99 & 51.3 & 9.0 \\
\hline Minimum & 9.19 & 26.9 & 1.83 & 3.31 & 48.8 & 7.3 \\
\hline SD & 1.37 & 0.8 & 0.30 & 0.68 & 0.9 & 0.5 \\
\hline SD (\% rel.) & 12.6 & 2.9 & 13.9 & 13.1 & 1.8 & 6.5 \\
\hline Median & 10.69 & 28.0 & 2.00 & 5.26 & 50.6 & 8.1 \\
\hline
\end{tabular}

Table 10: Bitter acids content of Kazbek variety in 2018 harvest in the Czech Republic (SD - standard deviation)

\begin{tabular}{|l|c|c|c|c|c|c|}
\hline & $\begin{array}{c}\alpha \text {-acids } \\
\% \mathrm{w}\end{array}$ & $\begin{array}{c}\text { cohumulone } \\
\% \text { rel. }\end{array}$ & $\begin{array}{c}\alpha \text {-acids } \\
\beta \text {-acids }\end{array}$ & $\begin{array}{c}\beta \text {-acids } \\
\% \mathrm{w} .\end{array}$ & $\begin{array}{c}\text { colupulone } \\
\% \text { rel. }\end{array}$ & $\begin{array}{c}\text { moisture } \\
\% \mathrm{w}\end{array}$ \\
\hline Average & 4.68 & 34.7 & 0.96 & 4.82 & 56.4 & 8.3 \\
\hline Maximum & 5.86 & 35.8 & 1.16 & 5.87 & 60.1 & 9.1 \\
\hline Minimum & 1.45 & 29.2 & 0.43 & 3.35 & 40.9 & 7.3 \\
\hline SD & 1.17 & 1.9 & 0.19 & 0.70 & 5.3 & 0.7 \\
\hline SD (\% rel.) & 25.0 & 5.4 & 20.1 & 14.6 & 9.4 & 8.2 \\
\hline Median & 5.01 & 35.3 & 1.00 & 4.93 & 57.9 & 8.3 \\
\hline $\begin{array}{l}\text { 5-year } \\
\text { average }\end{array}$ & 4.84 & 35.9 & 0.98 & 4.95 & 59.4 & 9.0 \\
\hline
\end{tabular}

Table 11: Bitter acids content of Saaz Late variety in 2018 harvest in the Czech Republic

\begin{tabular}{|l|c|c|c|c|c|c|}
\hline & $\begin{array}{c}\alpha \text {-acids } \\
\% \mathrm{w}\end{array}$ & $\begin{array}{c}\text { cohumulone } \\
\% \text { rel. }\end{array}$ & $\begin{array}{c}\alpha \text {-acids } \\
\beta \text {-acids }\end{array}$ & $\begin{array}{c}\beta \text {-acids } \\
\% \mathrm{w}\end{array}$ & $\begin{array}{c}\text { colupulone } \\
\% \text { rel. }\end{array}$ & $\begin{array}{c}\text { moisture } \\
\% \mathrm{w}\end{array}$ \\
\hline Average & 1.57 & 26.2 & 0.40 & 3.78 & 38.6 & 8.0 \\
\hline Maximum & 4.91 & 28.9 & 1.22 & 4.96 & 48.1 & 8.5 \\
\hline Minimum & 0.57 & 23.5 & 0.25 & 2.05 & 36.5 & 7.3 \\
\hline SD & 1.18 & 2.1 & 0.28 & 0.75 & 3.3 & 0.3 \\
\hline SD (\% rel.) & 75.5 & 7.8 & 68.8 & 19.8 & 8.6 & 4.0 \\
\hline Median & 1.15 & 25.8 & 0.31 & 3.87 & 37.3 & 8.0 \\
\hline $\begin{array}{l}\text { 4-year } \\
\text { average }\end{array}$ & 2.87 & 23.5 & 0.63 & 4.42 & 38.6 & 8.9 \\
\hline
\end{tabular}

The results of our (RIBM) harvest forecast of $\alpha$-bitter acids in the Saaz hops are among the values of the pre-harvest forecast (Žatec region $3.07 \%$ in the original) and the overall evaluation of all the purchasing samples carried out by the Hop Research Institute (HRI) (Žatec region $3.19 \%$ in the original) (Krofta 2019). The reason is mainly the difference in the methods used, the led conductance method according to Czech Technical Standard (ČSN 462520-15) has been used for the pre-harvest prognosis as well as the overall evaluation of the harvest.

The $\alpha$-bitter acids content of other Czech varieties in the harvest forecast was in relatively good agreement with the results of the overall harvest evaluation, especially taking into account the different methods of analysis;
Žatec region, RIBM / HRI: Sladek (5.0 / 5.2\%). Premiant $(5.0 / 5.9 \%)$, Agnus (10.0/11.1\%), Kazbek (4.3 / 5.0\%) and Saaz Late (1.4 / 1.7\%). (Krofta 2019).

\section{Acknowledgements}

This study was supported by the Ministry of Agriculture of the Czech Republic within the institutional support MZE-RO1918. 


\section{References}

Algazzali, V., Shellhammer, T., 2016. Bitterness Intensity of Oxidized Hop Acids: Humulinones and Hulupones J. Am. Soc. Brew. Chem. 74(1), 2016: 36-43, DOI 10.1094/ASBCJ2016-1130-01

Barborka, V., 2019: České chmelařství v přehledech ÚKZÚZ, Chmelařská ročenka 2018, VÚPS, Praha: 302-321. ISBN 978-80-86576-83-1.

Barborka, V., 2019a: Odrůdová skladba chmele. Chmelařská ročenka 2019, VúPS, Praha: 322-324 ISBN 978-80-86576-83-1. Czech Technical Standard, Hops Testing ČSN 462520, part 15 , Determination of lead conductance value of hops. Czech Standards Institute, 1997. (Česká technická norma, Zkoušení chmele ČSN 462520, část 15, Stanovení konduktometrické hodnoty chmele. Český normalizační institut, 1997).

Dresel, M., Vogt, C., Dunkel, A., Hofmann, T., 2016. The Bitter Chemodiversity of Hops (Humulus lupulus L.). J. Agric. Food Chem. 64: 77897799. doi.org/10.1021/acs.jafc.6b03933 Dusek, M., Olsovska, J., Krofta, K., Jurkova, M., Mikyska, A. 2014: Qualitative determination of acids and their transformation products in beer and hop using HR/AM-LC-MS/MS. J Agric. Food Chem 62: 76907697. dx.doi.org/10.1021/jf501852r EBC Analysis committee, 2010: Analytica-EBC. Nürenberg, Fachverlag Hans Carl, 2010,794 p. ISBN 978-3-418-00759-5

Forster, A., Gahr, A., 2014. A Comparison of the Analytical and Brewing Characteristics of Cascade and Comet Hop Varieties as Grown in Yakima (USA) and Hallertau (Germany). Brewing Science 67(11/12): 138-148.

Forteschi, M., Porcu, M. C., Fanari, M., Zinellu, M., Secchi, N., Buiatti, S., Passaghe, P., Bertoli, S., Pretti, L., 2018: Quality assessment of Cascade Hop (Humulus lupulus L.) grown in Sardinia. European Food Research and Technology doi.org/10.1007/s00217-018-3215-0 Published on line 03 January 2019.

Inui, T., Matsui, H., Hosoya, T., Kumazawa, S., Fukui, N., and Oka, K. 2016. Effect of Harvest Time and Pruning Date on Aroma Characteristics of Hop Teas and Related Compounds of Saaz Hops. J. Am. Soc. Brew. Chem. 74(4):231-241. https://doi.org/10.1094/ASBCJ-2016-4628-01
Inui, T., Okumura K., Matsui, H., Hosoya, T., Kumazawa, S., 2017. Effect of harvest time on some in vitro functional properties of hop polyphenols. Food Chem. 225: 69-75. https://doi.org/10.1016/j.foodchem.2017.01.002

Jelínek, L., Dolečková, M., Karabin, M., Hudcová, T., Kotlíková, B., Dostálek, P., 2012: Influence of growing area, plant age, and virus infection on the contents of hop secondary metabolites. Czech J. Food Sci. 30: 541-547. https://doi.org/10.17221/50/2012-CJFS

Kavalier, A.R., Litt, A., Ma, C., Pitra, N. J., Coles, M C., Kennelly, E. J., Matthews, P. D., (2011). Phytochemical and Morphological Characterization of Hop (Humulus lupulus L.) Cones over Five Developmental Stages Using High Performance Liquid Chromatography Coupled to Timeof-Flight Mass Spectrometry, Ultrahigh Performance Liquid Chromatography Photodiode Array Detection, and Light Microscopy Techniques. J. Agric. Food Chem. 59: 4783-4793. https://doi.org/10.1021/jf1049084

Krofta, K., 2019: Evaluation of Quality Indicators of Czech Hops from the Harvest of 2018 (Hodnocení kvalitativních ukazatelů českých chmelů ze sklizně 2018). Chmelařství, 92 (1-2)

Krofta, K., Mikyška, A., Jurková, M., Mravcová, L., Vondráčková, P., 2017: Determination of Bitter Compounds in Hops Effect of Crop Year and Hops Age. Kvasny Prum. 2017; 63(5): 241-247. https://doi.org/10.18832/kp201725

Mikyška, A., 2010: Sortimentní spotřeba chmele v tuzemských pivovarech. Pivovarský kalendář 2011, VúPS, Praha: 76-80. ISBN 978-80-86576-41-1.

Mikyška, A., Slabý, M., Jurková, M., Krofta, K., Patzak, J., Nesvadba, V., 2013: Saaz-Late- the Czech hop variety recommended for Czech beer. Kvasny Prum. 59(10-11): 296-305 https://doi.org/10.18832/kp2013031

Nesvadba, V., Polončíková, Z., Henychová, A., Krofta, K., Patzak, J., 2012. Czech hop varieties. Žatec: Chmelařský institut s.r.o. ISBN 978-80-87357-11-8. 